\title{
A (IN)DETERMINAÇÃO DO DIREITO NA FRONTEIRA ENTRE OS SISTEMAS JURÍDICO E POLÍTICO: UMA ANÁLISE A PARTIR DA DESCONSTRUÇÃO DE MITOS SOBRE $O$ POSITIVISMO E O PÓS-POSITIVISMO
}

THE (IN)DETERMINATION OF LAW AT THE BORDER BETWEEN LEGAL AND POLITICAL SYSTEMS: AN ANALYSIS FROM THE DECONSTRUCTION OF MYTHS ON POSITIVISM AND POSTPOSITIVISM

Fabrício Castagna Lunardi

\section{RESUMO}

O presente artigo tem como objetivo tematizar a questão da (in)determinação do direito no positivismo, no "pós-positivismo" e fora das teorias normativas. Desse modo, pretende-se perquirir em que medida essas teorias conseguem reduzir a incerteza do direito, ou, ao revés, se contribuem para ampliá-la. Para tanto, a pesquisa se desenvolve com base na opção de uma linha crítico-metodológica, sobretudo para desfazer algumas inconsistências propagadas acercas dessas teorias. Inicialmente, será tematizada a questão da (in)certeza do positivismo jurídico, à luz das teorias de Hans Kelsen e Herbert L. A. Hart, com foco no que propunham (ou não propunham) quando o direito não fornecia uma solução direta para o caso concreto apresentado. Analise-se a hipótese de que o positivismo jurídico trazia mais incertezas do que certezas. Mostra-se que positivistas como Kelsen e Hart já falavam em princípios, ainda que de forma não sistemática e, além disso, que o positivismo de Francesco Ferrara já desenvolvia os princípios com o caráter de normatividade. Após, será 
demonstrado que, muito antes da Constituição de 1988, a Corte Constitucional brasileira já aplicava diretamente os princípios, com força normativa. Ao final, conclui-se que a indeterminação do direito é uma contingência, bem como que ela se apresenta de forma paradoxal, pois possibilita a abertura para o futuro e conecta o direito à razão prática, mas, ao mesmo tempo, é um valor que deve se impor ao sistema, um postulado que sempre deve se exigir na tensão com o valor justiça.

PALAVRAS-CHAVE: Indeterminação do direito. Positivismo. Pós-positivismo. Teorias da argumentação.

\section{ABSTRACT}

This article aims to explore the question of (in)determination of law in positivism, "post-positivism" and out of normative theories. Then, it is intend to assert whether these theories can reduce the indetermination of the law, or, in reverse, if they contribute to enlarge it. To this end, research is developed based on the option of a critical-methodological approach, especially to unmake some inconsistencies propagated around these theories. Initially, the question of (in) certainty of legal positivism will be addressed, in the light of the theories of Hans Kelsen and Herbert LA Hart, focusing on what they proposed (or did not propose) when the law did not provide a direct solution to the specific case presented. Consider the hypothesis that legal positivism brought more uncertainty than certainty. It is shown that positivists like Kelsen and Hart already talked about principles, albeit in a non-systematic way, and, moreover, that Francesco Ferrara's positivism already developed the principles with the character of normativity. Afterwards, it will be demonstrated that, long before the 1988 Constitution, the Brazilian Constitutional Court already applied the principles directly, with normative force. Finally, it is concluded that the indetermination of the law is a contingency, and that it presents itself in a paradoxical way, it allows the opening to the future and connects the right to practical reason but at the same time is a value that should be imposed on the system, a postulated that should always be required in tension with justice value.

KEYWORDS: Indetermination of the law. Positivism. Postpositivism. Argumentation theories. 


\section{INTRODUÇÃo}

O presente artigo tem por objetivo investigar algumas problematizações clássicas das teorias normativas acerca da (in)determinação do direito, que serão tematizadas com base nelas e contra elas, mas com um novo olhar e a partir de uma perspectiva crítica. Nesse sentido, pretende-se problematizar a questão da (in)determinação do direito no positivismo, no "pós-positivismo" e, ainda, fora das teorias normativas do direito. Desse modo, pretende-se perquirir em que medida essas teorias conseguem reduzir a indeterminação do direito, ou, ao revés, se contribuem para ampliá-la. Nesse sentido, pretende-se desconstruir alguns mitos criados em torno do positivismo e do pós-positivismo, ou seja, narrativas de caráter simbólico-imagético que não condizem com a realidade, pois, ao simplificarem essas escolas de pensamento, acabam por não considerar aspectos que lhe são essenciais.

Para atingir esses escopos, a pesquisa se desenvolve com base na opção de uma linha crítico-metodológica. Entretanto, a par da perspectiva crítica, a investigação da presente pesquisa não se eximirá de ser propositiva, mediante a busca de algumas respostas para essas problematizações, ainda que sem a pretensão de resolvê-las.

Assim, o presente artigo foi dividido em três partes. Inicialmente, será tematizada a questão da (in)certeza do positivismo jurídico, à luz das teorias de Hans Kelsen e Herbert L. A. Hart, com foco no que propunham (ou não propunham) quando o direito não fornecia uma solução direta para o caso concreto apresentado. Para tanto, primeiramente, lança-se a proposição de que o positivismo jurídico trazia mais incertezas do que certezas, ao contrário do que muitas vezes é dito. Além disso, pretende-se mostrar que positivistas como Kelsen e Hart já falavam em princípios, ainda que de forma não sistemática e, além disso, o positivismo de Francesco Ferrara já desenvolvia os princípios com o caráter de normatividade. Após, será demonstrado que, muito antes da Constituição de 1988, a Corte Constitucional brasileira já aplicava diretamente os princípios, com força normativa.

Após expostas essas premissas, que refutam ou confirmam as críticas ao positivismo, é necessário analisar como autores "pós-positivistas" 
tratam da indeterminação do direito. Contudo, sob uma perspectiva crítica, analisar-se-á se os seus autores realmente conseguem atingir esse propósito, ou se, ao revés, contribuem para agravar esse "problema". Assim, inicialmente aborda-se a questão dos princípios em Ronald Dworkin, para mostrar que são indevidas algumas críticas que se lhe atribuem, bem como podem ser feitas outras. A seguir, trata-se da máxima da proporcionalidade em Robert Alexy à luz da crítica habermasiana, a fim de problematizar a questão e investigar se a utilização dessa "máxima" para solucionar a colisão entre princípios pode ou não agravar a indeterminação do direito.

Por fim, investiga-se como, diante da frustração com a indeterminação do direito e com a impossibilidade de vincular de forma absoluta o intérprete e o juiz, alguns autores acabam buscando respostas fora das teorias normativas do direito. Assim, no último item, pretende-se analisar as possíveis respostas para a indeterminação do direito a partir de autores céticos acerca das fronteiras do direito e da política, bem como a partir das teorias da argumentação, investigando-se as críticas que comumente lhe são feitas.

\section{A (IN)CERTEZA DO DIREITO NO CONTEXTO DO POSITIVISMO}

\section{A FALÁCIA DA CERTEZA DO POSITIVISMO E 0 DECISIONISMO}

O positivismo é uma escola de pensamento que surgiu na França no começo do século XIX, tendo como seus principais idealizadores Auguste Comte. Para Comte, o positivismo é uma corrente de pensamento filosófica, sociológica e política, que defende que o conhecimento científico é a única forma de conhecimento verdadeiro, de modo que uma teoria somente seria correta pudesse ser comprovada através de métodos científicos válidos. ${ }^{1}$

O positivismo de Comte sofreu variações em diversas em escolas de pensamento que também se denominaram positivistas. Exemplo disso são o positivismo jurídico ou juspositivismo, que tem como um dos seus principais expoentes Hans Kelsen (1998), para quem as fontes do Direito têm que ser buscadas apenas no próprio Direito, e o positivismo lógico, 
também conhecido como empirismo lógico, neopositivismo ou Círculo de Viena, mais ligado à filosofia da linguagem (LACERDA, 2009).

De outro lado, alguns neoconstitucionalistas, para justificar um novo modo de pensar do direito constitucional, buscam caminhos para dizer que o positivismo está superado, mas, muitas vezes, ressaltando aspectos que não são condizentes com esta escola de pensamento, ou dizendo que, para o positivismo, o juiz deveria ser apenas a "boca da lei" ${ }^{2}$. A esse respeito, Luís Roberto Barroso (2011, p. 263) afirma que "o positivismo pretendeu ser uma teoria do Direito, na qual o estudioso assumisse uma atitude cognoscitiva (de conhecimento), fundada em juízos de fato". Além disso, Barroso, ao citar o positivismo de Kelsen, aponta que uma das suas principais características é a "completude do sistema jurídico, que contém conceitos e instrumentos suficientes e adequados para solução de qualquer caso, inexistindo lacunas que não possam ser suprimidas a partir de elementos do próprio sistema" (BARROSO, 2011, p. 262). Na mesma linha de pensamento, Albert Calsamiglia (1998, p. 2018), ao buscar definir o neoconstitucionalismo, afirma que a indeterminação do direito está no cerne dessa teoria, bem como que os instrumentos oferecidos pela identificação das normas do legislador são insuficientes para a construção de uma teoria da adjudicação minimamente útil para o tomador de decisão, como se o positivismo não tratasse dessas questões.

Em primeiro lugar, não se pode confundir o que, para Kelsen, seria objeto da Ciência do Direito (Teoria Pura do Direito) - fornecer possíveis interpretações acerca das normas (1998, pp. 387/388), dando a moldura dentro da qual o juiz deve decidir (1998, p. 395) -, com a compreensão kelseniana sobre a atividade de aplicação das normas pelos juízes, o que denomina de "interpretação autêntica" (1998, p. 390).

Além disso, ao tentarem estabelecer um marco definido para mostrar algo novo, escolas de pensamento como o neoconstitucionalismo de Luís Roberto Barroso (2011) e Albert Calsamiglia (1998, p. 2018) simplificam ou, até mesmo, distorcem o positivismo kelseniano. Ao contrário do que afirmam, Kelsen reconhecia a possibilidade de existência de lacunas no ordenamento jurídico (KELSEN, pp. 273). Além disso, em Kelsen, essas lacunas não poderiam ser preenchidas pelo direito, senão pelo aplicador 
da norma, na medida em que somente este poderia levar em consideração elementos extrajurídicos (KELSEN, 1998, p. 393).

Para Kelsen, as normas jurídicas nunca são completas, de modo que sempre haverá uma relativa indeterminação da norma a aplicar. Para ele, essa indeterminação do ato normativo pode ser intencional ou não-intencional (KELSEN, PP. 388/389). Ao tratar da questão da indeterminação não-intencional, Kelsen (1998, p. 389) afirma que, no ato de aplicação do direito pelo juiz (interpretação autêntica), "a indeterminação do ato jurídico pode também ser a consequência não intencional da própria constituição da norma jurídica que deve ser aplicada pelo ato em questão". Nesse sentido, Kelsen (1998, p. 389) diz que há "pluralidade de significações de uma palavra ou de uma sequência de palavras em que a norma se exprime: o sentido verbal da norma não é unívoco, o órgão que tem de aplicar a norma encontra-se perante várias significações possíveis".

Com efeito, Kelsen já reconhecia o caráter indeterminado do direito e o papel criativo da decisão judicial, que chamava de interpretação autêntica. Entendia que a ciência do direito poderia conferir apenas "uma moldura dentro da qual existem várias possibilidades de aplicação" (KELSEN, 1998, p. 390).

Assim, para Kelsen, não seria possível se falar em uma única decisão como sendo a correta, na medida em que, estando dentro da moldura, haveria várias possibilidades. No entanto, apenas uma decisão se tornaria Direito positivo pelo órgão aplicador do Direito, especialmente pelo tribunal. ${ }^{3}$ Para Kelsen, dizer que uma sentença é "fundada na lei" significa apenas dizer que ela "é uma das normas individuais que podem ser produzidas dentro da moldura da norma geral” (KELSEN, 1998, p. 391).

Desse modo, segundo Kelsen (1998, p. 391), "não há absolutamente qualquer método - capaz de ser classificado como de Direito positivo segundo o qual, das várias significações verbais de uma norma, apenas uma possa ser destacada como 'correta'”. Para ele, os métodos de interpretação "conduzem sempre a um resultado apenas possível, nunca a um resultado que seja o único correto" (KELSEN, 1998, p. 392).

Desse modo, Kelsen é cético quanto à possibilidade de o Direito positivo vincular de forma absoluta o juiz, pois ele afirma que, relativamente 
ao Direito positivo, dentro da moldura, a produção da decisão (norma individual) é de livre apreciação do órgão julgador (KELSEN, 1998, p. 393).

Além disso, para Kelsen (1998, p. 393), saber qual das possibilidades dentro da moldura deve ser objeto da decisão judicial (norma individual) não é um problema da teoria do Direito, senão da política do Direito. Assim, se há atividade cognoscitiva do aplicador do Direito além da moldura, não se trata do conhecimento do Direito positivo, senão de outras normas do processo de criação jurídica, que podem ser "normas de Moral, normas de Justiça, juízos de valor sociais que costumamos designar por expressões correntes como bem comum, interesse do Estado, progresso, etc." (KELSEN, 1998, p. 393).

Então, poder-se-ia questionar o que aconteceria se a decisão judicial fosse produzida fora da moldura, ou seja, quando levasse em consideração outras normas do processo de criação jurídica, fora do Direito positivo. A esse respeito, para Kelsen (1998, p. 393), "do ponto de vista do Direito positivo, nada se pode dizer sobre a sua validade e verificabilidade".

É nesse aspecto que se pode acusar a Teoria Pura de Kelsen de levar a um decisionismo ${ }^{4}$, pois, no limite, ela não contribui para o controle da decisão judicial pelo direito. Talvez isso ocorra porque o objeto de Kelsen pretende ser uma teoria pura do direito, e não uma teoria da decisão judicial. Nesse aspecto, Kelsen não consegue limitar o caráter indeterminado do direito, sobretudo porque, para ele, o papel da ciência do direito deve ser apenas o de fornecer a moldura das possíveis interpretações ao aplicador do direito.

De outro lado, Herbert L. A. Hart também reconhecia a incerteza do direito em zonas limítrofes, bem como via a discricionariedade judicial como uma contingência, natural à imprecisão da linguagem. De acordo com o positivismo conceitual de Hart, o direito é baseado em fontes sociais determinadas - o que determina os limites do direito - e também na separação entre direito, moral e política, distinguindo-se os elementos jurídicos dos extrajurídicos. Segundo Hart (2009, p. 129), uma norma primária somente pode ser fonte do direito caso seja aceita por uma norma secundária de reconhecimento, o que seria fundamento do sistema jurídico.$^{5}$ De outro lado, o autor reconhece a imprecisão da linguagem nos textos legais e que "a discricionariedade que a linguagem lhe confere 
desse modo pode ser muito ampla, de tal forma que, se a pessoa aplicar a norma, a conclusão, embora possa não ser arbitrária ou irracional, será de fato resultado de uma escolha" (HART, 2009, p. 165).

Portanto, Hart também reconhece a incerteza do direito. Para ele, "a incerteza nas zonas limítrofes é o preço a pagar pelo uso de termos classificatórios gerais em qualquer forma de comunicação referente a questões factuais" (HART, 2009, p. 166). A par disso, o autor afirma que "a vida do direito consiste em grande parte em orientar tanto as autoridades quanto os indivíduos particulares através de normas precisas, que, diversamente das aplicações de padrões variáveis, não lhes exijam uma nova decisão a cada caso" (HART, 2009, p. 175).

Assim, Hart entende a problemática da textura aberta e da discricionariedade judicial como uma contingência, natural à linguagem, mas isso não elimina o caráter essencial do direito, sobretudo porque este confere, na maioria dos casos, uma solução decidida previamente e em abstrato pela fonte primária, conferindo-se maior certeza ao sistema jurídico.

Portanto, não é correto dizer que o positivismo é uma escola de pensamento que concebe o juiz como a boca da lei, que considera a completude do direito, que conduz a uma única resposta correta, ou que ignora a incerteza do direito, pois, em Kelsen e Hart, o direito é exatamente o contrário disso.

\section{A UTILIZAÇÃO DOS PRINCíPIOS NÃO É UMA INOVAÇÃO DO “PÓS POSITIVISMO”}

Atualmente, alguns autores que defendem o neoconstitucionalismo ou a existência de um pós-positivismo traçam como um marco dessas novas teorias do direito a normatividade dos princípios. Nesse sentido, por exemplo, Luís Roberto Barroso, ao defender a existência de um neoconstitucionalismo, coloca como um marco dessa teoria "o reconhecimento da normatividade dos princípios” (BARROSO, 2011, p. 288).

Kelsen efetivamente não tratava especificamente da normatividade dos princípios, até porque não era este o objeto da sua Teoria Pura. No entanto, Kelsen não ignorava a existência de princípios, pois fazia referência 
a diversos princípios que norteavam a interpretação e a aplicação de normas (regras). Vale dizer, Kelsen trata dos princípios que fundamentam a criação de normas jurídicas ou que orientam a sua aplicação, mas não de princípios aplicáveis diretamente a fatos concretos. ${ }^{6}$ Assim, por exemplo, Kelsen tratava do "princípio retributivo" (1998, p. 94), do "princípio da divisão do trabalho" (1998, p. 43), do "princípio da autodefesa” (1998, p. 43), do "princípio da não-contradição" (1998, p. 83/84), do "princípio da causalidade" (1998, p. 85), do "princípio ordenador" (1998, p. 85), do "princípio jurídico-positivo de que o desconhecimento do Direito não isenta da sanção pelo mesmo estatuída" (1998, p. 130), do "princípio da territorialidade" (1998, p. 350), do "princípio jurídico da efetividade" (1998, p. 376), do princípio da "apreciação dos interesses", formulado pela teoria da "ponderação dos interesses" 7 , dentre diversos outros. Aliás, no prefácio à segunda edição da sua obra Teoria Pura do Direito, Kelsen fala expressamente que pretende "dar um desenvolvimento mais consequente de princípios". 8

Portanto, Kelsen não ignorava a existência de princípios, ainda que, em sua obra, eles não tivessem o desenvolvimento conceitual, teórico e pragmático que possuem contemporaneamente, nem tivessem a mesma concepção do que os princípios, por exemplo, na obra de Dworkin.

De outro lado, o positivismo de Francesco Ferrara, embora preconizasse maior vinculação do juiz ao direito, ${ }^{9}$ já concebia a normatividade dos princípios. Segundo propõe, é papel da teoria do direito "extrair os princípios gerais da lei e de lhes dar o máximo desenvolvimento de expansão", a fim de que "surta mais completa e perfeita a aplicação do direito" (FERRARA, 1963, p. 188).

Para Ferrara, embora extraídos dos textos de lei, os princípios subsistem de forma autônoma à vontade objetivada do legislador. ${ }^{10} \mathrm{De}$ um lado, os "princípios jurídicos mudam com a transformação do material positivo". De outro, "devem sempre manter contacto com a vida, sob pena de se converterem em dogmas estéreis" (FERRARA, 1963, p. 178).

Assim, de acordo com o autor, um preceito de lei pode conter vários princípios, expressos ou derivados de dedução lógica. Além disso, o intérprete deve extrair dos princípios o máximo de consequências 
possíveis, estejam elas expressas no preceito legal ou estejam latentes no sistema. ${ }^{11}$

Ademais, Ferrara concebia, ainda, a possibilidade de se dar prevalência a um princípio geral em detrimento de uma norma específica, quando esse princípio geral for fundamental (no sentido de fundamental para o ordenamento) e a norma especial for acessória. ${ }^{12}$

Além disso, para Ferrara, caso se entenda o termo "lacuna" no sentido de vazios incolmatáveis no ordenamento jurídico, então o direito não possui lacunas, na medida em que, para todo caso não previsto expressamente, há uma norma jurídica desenvolvida e elaborada no sistema. Isso porque, de uma só disposição legal ou de um grupo de normas, é possível extrair um princípio jurídico mais amplo, do qual derivam consequências jurídicas. ${ }^{13}$ Além disso, se "a lei omitiu completamente a disciplina jurídica de todo um instituto, é necessário construí-la segundo os princípios de todo o sistema" (FERRARA, 1963, p. 159).

Ferrara afasta a tese de que os princípios gerais do direito sejam direito natural, ou estejam ligados à moral ou às exigências de justiça ou equidade (FERRARA, 1963, pp. 159/160). Segundo ele, "estes conceitos estão abandonados, e a doutrina reconhece que se deve tratar de princípios de direito, e, portanto, de direito positivo, de normas da legislação vigente" (FERRARA, 1963, p. 160). Assim, os princípios estão dentro do direito objetivo, estando ligado com os outros princípios, formando um todo orgânico. ${ }^{14}$

Portanto, até se pode dizer que Kelsen e Hart não tratavam da normatividade dos princípios, mas não é correta a afirmação genérica de que o positivismo não o fazia, pois Ferrara, por exemplo, reconhece expressamente a normatividade dos princípios, bem como a sua possibilidade de aplicação direta aos casos concretos.

Além disso, como se mostrará a seguir, no período em que o positivismo teve o seu apogeu, os tribunais brasileiros já reconheciam normatividade aos princípios, o que é um indicativo do descompasso entre a teoria do direito e a jurisprudência dos tribunais. 


\section{DESCONTRUINDO UM MITO: A FORÇA NORMATIVA DA CONSTITUIÇÃO E A APLICAÇÃO DIRETA DOS PRINCÍPIOS NÃO SÃO INAUGURADOS PELA CONSTITUIÇÃO BRASILEIRA DE 1988}

Segundo Luís Roberto Barroso, o marco histórico do neoconstitucionalismo no Brasil é a Constituição Federal de 1988 (BARROSO, 2011, p. 145). Para ele, "sob a Constituição de 1988, o direito constitucional no Brasil passou da desimportância ao apogeu em menos de uma geração. [...] 0 surgimento do sentimento constitucional no País é algo que merece ser celebrado" (BARROSO, 2011, p. 147). Contudo, essa afirmativa não possui qualquer base empírica.

Não se pretende negar aqui a importância da Constituição brasileira de 1988. Todavia, não é correto dizer que, antes dela, os textos constitucionais não possuíam normatividade ou não eram aplicados. Pelo contrário, a força normativa da Constituição não foi inaugurada pela Constituição de 1988, nem é possível traçar um marco único dentro do qual se possa falar do antes e do depois em termos de aplicação direta dos textos constitucionais.

Com efeito, antes da Constituição brasileira de 1988, já havia cotidianamente aplicação direta da Constituição, inclusive de princípios constitucionais. Fazendo-se uma busca de jurisprudência no sítio eletrônico do Supremo Tribunal Federal pela palavra "inconstitucionalidade", observa-se que, somente na base de coletânea de acórdãos (base bastante reduzida), anteriores a 1950, há mais de 120 ementas, sendo que, grande parte deles, declara a inconstitucionalidade de atos normativos infraconstitucionais com fundamento na aplicação de princípios e regras constitucionais. Fazendo-se uma busca tendo como parâmetro a palavra "inconstitucionalidade" no período imediatamente posterior, até a data da promulgação da Constituição Federal de 1988 (5/10/1988), são encontradas 3.251 ementas, sendo que, em grande parte delas, o STF declara a inconstitucionalidade de atos normativos infraconstitucionais.

De outro lado, a aplicação direta de princípios a fatos concretos pelo STF nos seus julgamentos já ocorria muito tempo antes da Constituição Federal de 1988, vale dizer, a normatividade dos princípios já era há muito 
tempo reconhecida. Por exemplo, fazendo-se uma pesquisa na coletânea de acórdãos do STF, do período de 1/1/1940 a 31/1/1949, ou seja, em apenas uma década antes da segunda metade do século XX, já é possível encontrar mais de 200 acórdãos que aplicam diretamente princípios a fatos concretos - ressaltando-se que provavelmente esse número é muito maior, tendo em vista que se trata apenas de pesquisa feita numa coletânea de acórdãos disponibilizada pelo STF (base de dados reduzida). São casos, por exemplo, de aplicação do princípio da irretroatividade da lei penal mais grave ${ }^{15}$, do princípio "Sententia debet esse conformis libello"16, do princípio de que "a falta de recurso administrativo não prejudica a amplitude da defesa judicial"17, do princípio da "acusatio nata"18, do princípio "nullum crimen, nulla poena sine lege"19, do princípio da liberdade contratual ${ }^{20}$, do princípio da "lex mitior" 21 , do princípio da aplicação retro operante da lei mais branda ${ }^{22}$.

Esses dados mostram que a aplicação direta de princípios a casos concretos era cotidiana pelo STF. Além disso, com a leitura dos referidos acórdãos - alguns, exemplificativamente, nas notas de rodapé -, é possível notar que a aplicação desses princípios ocorria mais indiscriminadamente do que atualmente, até mesmo porque, à época, muitos desses princípios sequer estavam positivados em textos legais.

Assim, no contexto institucional brasileiro, não se pode dizer que a normatividade dos princípios é uma criação dos "pós-positivistas", tampouco que, no Brasil, foi inaugurada a partir da Constituição brasileira de 1988.

Além disso, esses dados mostram empiricamente que, ao menos no Brasil, a indeterminação do direito não é um fenômeno que ocorreu recentemente, tampouco que é decorrência da nova forma de aplicar os princípios. Pelo contrário, os novos "métodos" de interpretação tendem a colocar mais balizas para os julgamentos, ainda que, por vezes, a sua má utilização possa levar a resultados opostos. 


\section{AUTORES “PÓS-POSITIVISTAS” E A TENTATIVA DE COMBATER A DISCRICIONARIEDADE FORTE DO POSITIVISMO}

\section{OS PRINCÍPIOS EM DWORKIN E A INDETERMINAÇÃO DO DIREITO}

Alguns autores afirmam que os princípios são os grandes responsáveis pela indeterminação do direito, na medida em que eles albergam valores, o que poderia vulnerar o caráter deontológico do direito ao absorver elementos axiológicos.

Porém, é incorreto dizer que os princípios implicam maior indeterminação do direito porque albergam valores, enquanto que as regras seriam normas de "se, então". Isso porque os valores também entram no sistema jurídico mediante regras. ${ }^{23}$ Ademais, embora se possa afirmar que comumente os princípios são mais gerais e imprecisos que as regras, essa não é uma relação necessária, senão meramente eventual. ${ }^{24}$

De outro lado, muitas vezes Dworkin é apontado como sendo o autor responsável pelo "problema" da insegurança diante da indeterminação do direito. Contudo, tal conclusão é falaciosa.

Em primeiro lugar, a indeterminação do direito é uma contingência e não pode ser relacionada diretamente aos princípios. Além disso, Dworkin, ao tratar dos princípios como padrões com normatividade, não pretendia ampliar a insegurança, senão reduzi-la, pois buscava reduzir a discricionariedade forte do positivismo, pela exigência de coerência e de respeito aos precedentes pelos juízes.

Ao questionar o positivismo, Dworkin diferencia dois tipos de discricionariedade, a forte e a fraca. A discricionariedade fraca diz respeito à circunstância de que uma regra não pode ser aplicada automaticamente, senão com base no julgamento do aplicador. Também está relacionada, segundo Dworkin, ao fato de uma autoridade poder tomar uma decisão em última instância e esta não poder ser revista nem cancelada por nenhuma outra autoridade. Todavia, a de Dworkin ao positivismo não está relacionada a essa espécie de discricionariedade, senão à discricionariedade forte, que diz respeito à ausência de padrões para a tomada de decisão. ${ }^{25}$ 
Para combater a discricionariedade forte do positivismo é que Dworkin utiliza os princípios, os quais possuem normatividade, ou seja, são padrões de observância obrigatória, assim como as regras. Assim, para Dworkin, os princípios podem limitar a discricionariedade forte, na medida em que, mesmo nos casos difíceis, um conjunto de princípios pode ditar um resultado. ${ }^{26}$

Dworkin afirma que a diferença entre regras e princípios é de natureza lógica. Para ele, "os dois conjuntos de padrões apontam para decisões particulares acerca da obrigação jurídica em circunstâncias específicas, mas distinguem-se quanto à natureza da obrigação que oferecem. As regras são aplicáveis à maneira do tudo-ou-nada" (DWORKIN, 2010, p. 39). De outro lado, "os princípios possuem uma dimensão que as regras não têm - a dimensão do peso ou importância” (DWORKIN, 2010, p. 42). Assim, "quando os princípios se intercruzam [...], aquele que vai resolver o conflito tem de levar em conta a força relativa de cada um. [...] As regras não tem essa dimensão [...] Se duas regras entram em conflito, uma delas não pode ser válida" (DWORKIN, 2010, pp. 42/43).

Dworkin também mostra que princípios não se confundem com política. Para ele, política é "aquele tipo de padrão que estabelece um objetivo a ser alcançado, em geral uma melhoria em algum aspecto econômico, político ou social da comunidade". De outro lado, princípio é "um padrão que deve ser observado, não porque vá promover ou assegurar uma situação econômica, política ou social considerada desejável, mas porque é uma exigência de justiça ou equidade ou alguma outra dimensão da moralidade". ${ }^{27}$

Contudo, a concepção dworkiniana de direito se afasta do convencionalismo e do pragmatismo jurídico, pois concebe o direito como integridade. ${ }^{28} 0$ Direito é o resultado de uma interpretação construtiva, que tem como propósito apresentar, em sua melhor luz, o objeto ou a prática a serem interpretados (ou seja, o próprio Direito), a partir do princípio da integridade. Nesse sentido, o direito, entendido como um todo principiológico, teria sempre respostas para os casos concretos.

Assim, a interpretação construtiva em Dworkin não autoriza o juiz criar direitos a partir de suas próprias concepções políticas ou morais subjetivas, pois, ao contrário, esse processo interpretativo obriga o juiz 
a buscar na comunidade de princípios a solução mais adequada para o caso, considerando as práticas políticas e jurídicas dessa comunidade.

Contudo, para lidar com o problema da indeterminação do direito e propor a formulação do direito como integridade, Dworkin parte do juiz Hércules, que ele próprio define como "um juiz imaginário, de capacidade e paciência sobre-humanas, que aceita o direito como integridade" (DWORKIN, 2007, p. 287). Com esse juiz ideal, para Dworkin, seria possível se chegar, em todos os casos, a uma decisão idealmente válida. ${ }^{29}$ Segundo Dworkin, os juízes seriam capazes de fazer uma interpretação construtiva, como se fossem autores de um "romance em cadeia", participando de um projeto compartilhado com comunidade (DWORKIN, 2007, pp. 375-286).

Entretanto, ao depositar o cerne da sua teoria nesse juiz ideal, acaba por fragilizar a sua tese, pois os juízes reais não possuem a capacidade de conceber a moralidade política da comunidade.

Assim, Dworkin pretende, com os princípios, contrapor-se à discricionariedade forte do positivismo. Todavia, ainda que os princípios possam ser capazes de permitir decisões dentro daquilo que Dworkin considera como sendo direito, a sua teoria não consegue pôr fim à discricionariedade judicial.

\section{A MÁXIMA DA PROPORCIONALIDADE E O “PROBLEMA" DA INDETERMINAÇÃO DO DIREITO}

Inicialmente, é importante ressaltar que a proporcionalidade (ou ponderação) não é uma inovação dos "pós-positivistas", ainda que fosse utilizada para ponderar bens e interesses, e não valores. Como ressalta Wálber Carneiro, "embora a questão surja com ares de ineditismo, a ponderação constitui um recurso presente na metodologia jurídica desde a segunda metade do séc. XIX" (CARNEIRO, 2009, p. 201).

Com efeito, Kelsen tratava do princípio da "apreciação dos interesses" (1998, p. 392), formulado pela teoria da "ponderação dos interesses". Aliás, Kelsen afirmava que tal princípio era "tão-só uma formulação, e não qualquer solução, do problema que aqui nos ocupa" (1998, p. 392). Isso porque ele "não fornece a medida ou critério objetivo segundo o 
qual os interesses contrapostos possam ser entre si comparados e de acordo com o qual possam ser dirimidos os conflitos de interesses" (1998, p. 392). Para Kelsen, diante da necessidade de uma interpretação, esse princípio da apreciação dos interesses deixa "várias possibilidades em aberto", ou seja, não contém "qualquer decisão sobre a questão de saber qual dos interesses em jogo é o de maior valor", mas deixam esta decisão, "a determinação da posição relativa dos interesses, a um ato de produção normativa que ainda vai ser posto - à sentença judicial, por exemplo" (KELSEN, 1998, p. 392).

A par disso, contemporaneamente, tem-se desenvolvido a proporcionalidade como uma máxima, critério, método ou técnica para tratar da questão da colisão entre princípios. Um dos principais autores que se dedicam a essa temática é Robert Alexy.

Alexy propõe critérios para a diferenciação entre princípios e regras. Segundo o autor, os princípios são normas que ordenam que algo seja realizado na maior medida possível dentro das possibilidades fáticas e jurídicas, enquanto as regras são normas que são sempre satisfeitas ou não satisfeitas. Logo, os princípios contêm "mandamentos de otimização", pois devem ser aplicados na maior medida possível (ALEXY, 2011b, pp. 90/91).

Nesse ínterim, Alexy estabelece uma estreita conexão entre a teoria dos princípios e a máxima da proporcionalidade. Segundo o autor, "princípios são mandamentos de otimização em face das possibilidades jurídicas e fáticas. A máxima da proporcionalidade em sentido estrito, ou seja, exigência de sopesamento, decorre da relativização em face das possibilidades jurídicas" (ALEXY, 2011b, p. 117). Com efeito, quando uma norma de direito fundamental com caráter de princípio (e não de regra) colide com um princípio contrário, a possibilidade jurídica para a aplicação dessa norma depende do conteúdo do princípio de sentido antagônico.

Assim, diante dessa necessidade de sopesamento entre os princípios contrários, surge a máxima da proporcionalidade em sentido estrito. De outro lado, as máximas da necessidade e da adequação surgem do fato de os princípios serem mandamentos de otimização, vale dizer, de 
que devem ser aplicados da forma mais ampla possível (ALEXY, 2011b, pp. 117/118).

Dessa forma, Alexy fundamenta que o princípio da proporcionalidade (constituído por necessidade, adequação e proporcionalidade em sentido estrito) decorre das normas fundamentais, na medida em que tenham caráter de princípio (ALEXY, 2011b, p. 120).

Ao compreender os direitos fundamentais como princípios ou valores, Alexy usa a proporcionalidade (ponderação ou sopesamento) como uma máxima, hábil para solucionar os problemas de conflito entre os direitos fundamentais.

Embora com ampla aceitação no Brasil, seja no plano teórico, seja no campo jurisprudencial - por vezes, de forma até exagerada ou desvirtuada -, a proporcionalidade não é o único critério para solução da colisão entre direitos fundamentais, tampouco é indene de críticas quanto à sua qualificação para tanto.

Jürgem Habermas faz diversas críticas à máxima da proprocionalidade de Alexy, como critério para resolver o conflito entre direitos fundamentais. Entende que, se os direitos individuais forem transformados em bens ou valores, como quer Alexy, ruirá a viga-mestra de normas e princípios do direito, crescendo o perigo de juízos irracionais, porque os argumentos funcionalistas crescem sobre os normativos. ${ }^{30}$

Além disso, Habermas - concordando com os supostos de Dworkin em relação ao "método" da interpretação construtiva - afirma que colocar a discussão sobre a colisão entre os direitos fundamentais no plano do sopesamento de valores implica reduzir a importância desses direitos, pois os valores possuem caráter teleológico, enquanto princípios e regras possuem caráter deontológico (HABERMAS, 2010, p. 258).

Ademais, para Habermas, normas válidas obrigam seus destinatários a um determinado comportamento que preenche expectativas generalizadas, enquanto que valores são simples preferências compartilhadas intersubjetivamente, vale dizer, analisa-se apenas se determinados bens são mais atrativos do que outros. ${ }^{31}$ Assim, para o autor, direitos fundamentais não podem ser analisados sob a ótica de custos e vantagens. ${ }^{32}$ Nesse ponto, Habermas adere à proposta de Dworkin, no sentido de que os direitos fundamentais devem ser 
entendidos como princípios (e não como valores), bem como que, nos casos difíceis (ex.: colisão entre direitos fundamentais), as decisões judiciais, para o caso singular (único e irrepetível), devem ser tomadas a partir do contexto do direito vigente racionalmente reconstruído (HABERMAS, 2010, p. 261). Assim, para Habermas (e também para Dworkin), a decisão deve ser tomada racionalmente, reconciliando as decisões tomadas pelo legislador no passado com a decisão justa a ser tomada no presente, satisfazendo simultaneamente os critérios de segurança do direito e aceitabilidade racional. ${ }^{33}$

Robert Alexy, no entanto, em artigo escrito para rebater as críticas de Habermas, diz que a proporcionalidade (ou sopesamento) não se efetiva arbitrariamente ou não-refletidamente, como afirma Habermas, pois se funda em graus de intensidade de intervenção como fundamento, em juízos de correção, que são juízos racionais. Além disso, Alexy (2011a, pp. 731/732) ressalta que, na medida em que têm um núcleo resistente (ou núcleo essencial), os direitos fundamentais ganham sobreproporcionalmente em fortidão quando aplicados com a regra do sopesamento, e isso estabelece o que Habermas chama de "muro de fogo" (ou viga-mestra).

De qualquer forma, ainda que se possa admitir a proporcionalidade como critério para a solução de colisão entre princípios, no julgamento de casos concretos, dificilmente ele será o único critério utilizado. Se fosse possível a sua aplicação no plano abstrato, como norma em tese, sem considerar os casos concretos, a máxima da proporcionalidade até poderia ser analisada isoladamente. No entanto, como pressupõe o próprio Alexy, a máxima da proporcionalidade não tem como ser aplicada sem a consideração do caso concreto. Por conseguinte, a interpretação pressupõe a aplicação de outros métodos de interpretação, como o literal ou gramatical, o teleológico, o sistemático, dentre outros.

Por exemplo, quando se analisa a questão do aborto de feto anencefálico, antes de se fazer o sopesamento entre os direitos fundamentais em jogo (com caráter de princípio), é preciso interpretar o texto constitucional, para tentar se extrair possíveis significados. Além disso, interpreta-se a legislação penal para buscar possibilidades de aplicação analógica. No entanto, sem encontrar uma solução definitiva para resolver a colisão 
entre o bem jurídico vida do feto e a integridade física e psicológica da mãe, o intérprete precisará buscar o próprio conceito de início da vida, que terá diferentes concepções de acordo com cada cultura, religião, tribo etc., sendo que provavelmente as fronteiras do sistema jurídico não permitirão uma resposta definitiva.

A proporcionalidade exige do intérprete a avaliação da necessidade, da adequação e sopesamento, o que não livra o direito do "problema" do poder discricionário julgador (no sentido de discricionariedade fraca, de Dworkin), ainda que a argumentação seja objetiva.

Por todas essas razões, a máxima da proporcionalidade não conduz a uma única resposta correta, nem é capaz de ser aplicada isoladamente. Assim, ainda que possa ser mais um critério na tentativa de vincular o intérprete e o julgador ao sistema jurídico, não resolve a questão da indeterminação do direito.

\section{TENTATIVAS DE REDUÇÃO DA INDETERMINAÇÃO FORA DAS TEORIAS NORMATIVAS DO DIREITO}

\section{ENTRE NORMATIVISTAS E CÉTICOS: A INDETERMINAÇÃO DO DIREITO NÃO TRANSFORMA DIREITO EM POLÍTICA}

Céticos quanto à possibilidade de as teorias jurídico-normativas vincularem a interpretação e a aplicação do direito pelo juiz, alguns autores acabam apagando a linha divisória entre os sistemas jurídico e político, ou confundido direito com política. Alexandre Araújo Costa, por exemplo, conclui que "admitir claramente o caráter político da atuação judicial é o primeiro passo para que ela possa se tornar politicamente útil e democraticamente legítima" (COSTA, 2013, p. 43).

Contudo, não se pode dizer que a atividade judicial é eminentemente política, tampouco que deve operar dentro do sistema político. Pelo contrário, admitir que a atividade judicial é política implica romper os próprios limites entre os sistemas do direito e da política, o que pode ser desastroso. 
Em primeiro lugar, porque, na imensa maioria dos julgamentos, há constante aplicação de regras legais e de precedentes jurisprudenciais. Os casos fáceis ou simples são a regra; os casos difíceis ou complexos, a exceção. Com efeito, na praxe judicial, há um percentual muito pequeno de questões de alta indagação. Assim, não se podem tomar as exceções como regra, tampouco subverter a lógica que diferencia direito e política.

Além disso, dizer que, em algumas situações específicas, quando não há regra que se aplique especificamente à questão, ou quando a sua aplicação é flagrantemente injusta, haverá maior discricionariedade do juiz, não é o mesmo que dizer que o direito foi transformado em política.

O sistema jurídico, como qualquer sistema com complexidade complexa $^{34}$, necessita atuar com seletividade no ambiente, reduzindo complexidade para poder operar. Com efeito, não seria possível responder, ponto por ponto, a imensa gama de possibilidades e variantes do ambiente. Desse modo, é preciso que ocorra a redução da complexidade, vale dizer, que o sistema seja menos complexo que o meio. ${ }^{35}$

Como aponta Luhmann, "os sistemas reais do mundo evolutivo" se encontram no campo dos "sistemas que dispõem de possibilidade de relação somente seletiva" de seus elementos. Desse modo, "a complexidade é [...] a necessidade de manter uma relação apenas seletiva entre os elementos" (LUHMANN, 2011, p. 185). Em razão da complexidade e da necessária seletividade ${ }^{36}$, o sistema jurídico é contingente, de modo que não consegue incluir todas as possibilidades de variação.

Assim, é natural que o sistema jurídico, por operar mediante a seletividade e a redução de complexidade em relação ao ambiente, não dê respostas diretas do tipo "se, então" para todas as situações fáticas possíveis. Contudo, essa impossibilidade de responder a todas as situações não transforma o sistema em ambiente, nem implica romper a diferenciação entre os sistemas. Essas variações no ambiente irritam o sistema, de modo que o sistema pode ser modificado, pelo acoplamento estrutural. ${ }^{37}$

Nesse ínterim, como ressalta Marcelo Neves, a teoria sistêmica coloca a Constituição como fator e produto da diferenciação entre política e direito como subsistemas da sociedade. Nesse sentido, a Constituição 
pode ser definida como o acoplamento estrutural entre direito e política (NEVES, 2008, pp. 95-97).

Luhmann salienta que existe "possibilitação" e "estimulação" recíprocas entre os sistemas do direito e da política. ${ }^{38}$ Contudo, eles se reproduzem dentro dos seus próprios limites. Assim, para Luhmann, se não funcionasse a capacidade de distinguir os sistemas jurídico e político, haveria o caos e a simplificação extrema. ${ }^{39}$

Desse modo, existe uma abertura do sistema do direito em relação ao sistema da política, mas não há confusão entre eles. Aliás, é o fechamento do sistema que permite a sua abertura. Ademais, a decisões judiciais desviantes irritam o sistema, oportunizando que este dê respostas, seja pela modificação do próprio sistema, seja pela correção dessa decisão.

Portanto, dizer que a atividade do juiz é eminentemente política não é adequado, nem contribui para o "problema" da indeterminação do direito, pois, pelo contrário, implica agravá-lo, ao esmaecer as fronteiras entre Direito e Política.

\section{AS TEORIAS DA ARGUMENTAÇÃO E A CRÍTICA DE INDETERMINAÇÃO DO DIREITO}

As teorias da argumentação costumam ser alvo de diversas críticas sob a perspectiva da indeterminação do direito, com base no argumento de que flexibilizariam o próprio direito. Não se pretende aqui mostrar que as teorias da argumentação podem ser a solução esse "problema", nem assumir seus supostos, senão investigar se elas são capazes de agravar a indeterminação do direito ou se, ao revés, podem ser utilizadas para reduzi-la.

Inicialmente, é preciso esclarecer que, contemporaneamente, os teóricos da argumentação têm retomado a retórica aristotélica, ligada à dialética, mas que não se aproxima da retórica sofística, relacionada à arte de persuadir.

Assim, as teorias da argumentação jurídica, ao analisarem o discurso judicial - ainda que este não seja o seu único objeto -, comumente têm em consideração aspectos situacionais do discurso, como a premissa 
de que o objetivo das partes no processo judiciário não é a busca da verdade. Na medida em que cada uma defende os seus próprios interesses, estariam mais preocupadas em persuadir do que convencer. ${ }^{40}$ Essa perspectiva, se considerada isoladamente, poderia dar ensejo a dizer que a retórica permitiria ao orador vencer o debate mesmo defendendo maus argumentos. ${ }^{41}$ Aqui residiriam os questionamentos às teorias da argumentação acerca da irracionalidade do discurso judicial e da indeterminação do direito.

Porém, as teorias da argumentação contemporâneas têm por objetivo evitar essa irracionalidade argumentativa, a partir de técnicas de controle - ainda que se possa afirmar que as suas tentativas são frustradas. Com efeito, para que não ocorra a degeneração do discurso judicial, onde todo argumento poderia ser admitido, as teorias da argumentação criam técnicas de controle das premissas, o que conferiria racionalidade argumentativa a esse discurso.

Perelman e Tyteca (2005, pp. 33-37), para garantir a racionalidade do discurso em geral, propõem que o orador faça uma representação do auditório universal, mecanismo que proporcionaria um teste para aferir se qualquer argumento seria capaz de convencer um auditório composto por todas as pessoas normais, ou seja, de modo possibilitar a análise da adequação desse argumento. ${ }^{42}$

Seguindo essa perspectiva, Neil Maccormick aponta que, do ponto de vista da racionalidade prática, a questão da teoria da argumentação como justificação envolve a perspectiva de convencer qualquer instância decisória racional, ou seja, se há a efetiva adequação do argumento, não tendo relação com o fato de que convenceu ou não um juiz em particular, nem se houve persuasão imediata e concreta (MACCORMICK, 2008, p. 26).

Entretanto, quando se assume a tópica e a retórica, surge a problematização referente à racionalidade argumentativa do discurso judicial e, como corolário, a questão da incerteza que ele causaria no sistema jurídico e, por conseguinte, ao próprio Estado de Direito.

Diante da importância da certeza jurídica, acompanhada dos princípios da segurança jurídica e da garantia do cidadão contra interferências arbitrárias, Maccormick (2008, p. 23) propõe reconciliar o lugar-comum do "caráter argumentativo do direito" com a ideologia do "Estado de 
Direito". Ele afirma que a certeza jurídica não é o único valor dentro do Estado de Direito, ainda que se espere que juízes e legisladores lhe concretizem na maior medida possível. Nesse sentido, a certeza do Direito seria excepcionável, na medida em que o caráter argumentativo do Direito albergaria a proteção arbitrária contra os governos (MACCORMICK, 2008, p. 38). Desse modo, Maccormick (2008, p. 22) aponta para a importância do caráter argumentativo do Direito em uma sociedade plural, ao mesmo tempo que propõe que deva ser conciliado com a segurança jurídica.

Diante da constante referência a conexões de problemas, o discurso judicial também contém, sobretudo procedimentalmente, a possibilidade de controle das premissas, que serão admitidas ou rechaçadas no decorrer da argumentação. Com base nessa possibilidade de controle das premissas, Tercio Sampaio Ferraz Jr. (2015, p. 105) afirma que é possível distinguir, no discurso judicial, aspectos formais de controle (se a decisão é ou não correta - a partir da análise das premissas) e aspectos situacionais de controle (possibilidade de assumir as premissas e recusar a decisão, ou de questionar as premissas e aceitar a decisão). Desse modo, no discurso judiciário, assim como nas discussões-contra em geral, a informação é sempre seletiva, na medida em que implica um ato de escolha (seleção) por parte do receptor, que é, assim, um intérprete. Por conseguinte, a discussão-contra judicial é basicamente hermenêutica e estabelece, nesse caso, a obrigação de interpretar (FERRAZ JR., 2015, p. 106).

A par das diferenças do foco entre os teóricos da argumentação contemporâneos, fica claro que, entre eles, existe o propósito de estabelecer técnicas de controle discursivo, o que, segundo propõem, conferiria racionalidade argumentativa ao discurso.

Portanto, ainda que não se possa defender a possibilidade de existência de uma única resposta correta a partir do discurso judicial, este possibilita o controle discursivo. E é essa possibilidade de controle que garante racionalidade argumentativa, na medida em que limita os argumentos possíveis e impede a degenerescência do discurso, reduzindo a indeterminação do direito ${ }^{43}$, embora não se possa jamais suprimi-la pragmaticamente.

Desse modo, a indeterminação relativa do direito é uma contingência, mas não se pode dizer que seja maximizada pelo discurso judicial, nem 
pelas teorias da argumentação. Se, de um lado, a tópica e a retórica, na pragmática do discurso judicial, não conduzirão a encontrar uma única resposta correta, possibilitam fórmulas de procura para melhores opções, o que distancia as teorias da argumentação contemporâneas do arbítrio, do realismo e do decisionismo - sendo inadequadas as pechas que às vezes se lhes impõem.

Portanto, não é correto afirmar que as teorias da argumentação contribuem para a indeterminação do direito, já que permitem criar critérios de controle de discurso das decisões judiciais. Contudo, também não conseguem eliminá-la.

\section{CONSIDERAÇõES FINAIS}

Embora atualmente o positivismo jurídico seja alvo de diversas críticas - muitas delas legítimas - ou seja visto como um modelo teórico em grande medida superado, não se pode dizer que é uma escola de pensamento que concebe o juiz como a "boca da lei", que parte do dogma da completude do sistema jurídico, que conduz a uma única resposta correta, ou que ignora a indeterminação do direito. Aliás, o positivismo de Kelsen e de Hart é exatamente o contrário de tudo disso.

Também não é adequada a crítica de que os positivistas como Kelsen e Hart não abordavam os princípios, embora efetivamente não tivessem o tratamento teórico normativo de "pós-positivistas". Além disso, é incorreta a afirmação genérica de que o positivismo não reconhecia a normatividade dos princípios, porque, como se demonstrou, Ferrara já concebia a sua força normativa.

Ademais, não se pode confundir o plano teórico com o que efetivamente era ocorria nos tribunais. Com efeito, por dados empíricos apresentados, a aplicação direta de princípios a casos concretos era cotidiana pelo STF mesmo antes da primeira metade do século XX. Portanto, isso indica que havia um descompasso entre o positivismo de Kelsen e Hart no seu apogeu e a jurisprudência da Corte Constitucional brasileira.

Por tais razões, não se deve transpor sem contextualização o positivismo e o "pós-pós-positivismo" sem antes considerar a realidade 
institucional brasileira e a jurisprudência nacional. Com efeito, no contexto institucional brasileiro, não se pode dizer que a normatividade dos princípios é uma criação dos "pós-positivistas", tampouco que, no Brasil, foi inaugurada a partir da Constituição brasileira de 1988. Nesse tocante, demonstrou-se que, empiricamente, no Brasil, a indeterminação do direito não é um fenômeno recente, tampouco que é decorrência da nova forma de aplicar princípios.

Além disso, os "novos métodos" de interpretação, decorrentes do reconhecimento da força normativa da constituição e da normatividade dos princípios, como a proporcionalidade, tendem a colocar mais balizas para os julgamentos, ainda que, por vezes, a sua má utilização possa levar a resultados opostos.

De outro lado, não procede a crítica feita a Dworkin quando se afirma que ele contribuiria para a indeterminação do direito ao reconhecer a normatividade de uma comunidade de princípios na definição da decisão de um caso concreto. Com efeito, Dworkin pretende, com os princípios, contrapor-se à discricionariedade forte do positivismo. Todavia, ainda que os princípios possam ser capazes de permitir decisões dentro daquilo que Dworkin considera como sendo direito, a sua teoria não põe fim à discricionariedade judicial, nem pretende combater aquilo que chama de discricionariedade fraca.

Portanto, ao contrário do que alguns "neoconstitucionalistas" como Luís Roberto Barroso afirmam, a completude do ordenamento jurídico não era preconizada por positivistas como Kelsen e Hart, nem a incompletude é a marca de Dworkin. Pelo contrário, enquanto esses autores positivistas concebiam a possibilidade de lacunas em zonas limítrofes, que deveriam ser preenchidas pelo juiz, Dworkin concebe o direito como integridade, na medida em que o direito seria capaz de dar respostas a todos os casos concretos, pois concebido como um todo principiológico.

De outro lado, as teorias não normativas também não resolvem o "problema" da indeterminação do direito. A indeterminação relativa do direito é uma contingência, mas não se pode dizer que seja maximizada pelo discurso judicial, nem pelas teorias da argumentação. Se, de um lado, a tópica e a retórica, na pragmática do discurso judicial, não conduzirão a encontrar uma única resposta correta, possibilitam fórmulas de procura 
para as melhores opções, o que distancia as teorias da argumentação contemporâneas do arbítrio, do realismo e do decisionismo. Assim, não é correto afirmar que as teorias da argumentação contribuem para a indeterminação do direito - uma vez que pretendem estabelecem critérios de controle de discurso das decisões judiciais -, mas elas também conseguem eliminá-la.

De outro lado, reconhecer a existência de uma discricionariedade fraca como inerente ao sistema (no sentido dworkiniano) não é o mesmo que reconhecer o arbítrio. Assim, não é correto dizer que atividade judicial é eminentemente política, tampouco que deve operar dentro do sistema político. Pelo contrário, admitir que a atividade judicial é política implica romper os próprios limites entre Direito e Política.

Por fim, não se pretende aqui apresentar uma solução absoluta para a questão da indeterminação do direito, tampouco apontá-la como um "problema" a ser resolvido. A indeterminação do direito é uma contingência, cada vez mais presente diante da hipercomplexidade da sociedade. Nesse sentido, apresenta-se de forma paradoxal, na medida em que, de um lado, a indeterminação do direito é o que possibilita a abertura para o futuro e conecta o direito à razão prática, mas, ao mesmo tempo, se apresenta como um valor que deve se impor ao sistema, ou seja, como algo que deve se exigir do órgão aplicador da norma, tanto pelas teorias normativas do direito, quando do ponto de vista institucional. Assim, ainda que a certeza do direito exista em maior ou menor medida, ela é sempre algo que falta, ou seja, é um postulado que sempre deve se exigir na tensão com o valor justiça.

\section{NOTAS}

1 Nesse sentido: LACERDA, 2009.

2 Na clássica concepção de Montesquieu (2005, p. 175), os juízes deveriam ser a "boca que pronuncia as palavras da lei", "seres inanimados que não podem nem moderar a sua força, nem seu rigor". Ocorre que essa concepção clássica de tripartição de poderes, que continua sendo seguida ou é revisitada por parte dos teóricos do direito contemporâneos, reduz complexidade ao ignorar os fatos sociais, pois, ainda que com variações, tem como pressuposto o dogma da completude da lei.

3 "Sendo assim, a interpretação de uma lei não deve necessariamente conduzir a uma única solução como sendo a única correta, mas possivelmente a várias soluções que - na medida em que apenas sejam aferidas pela lei a aplicar - têm igual valor, se bem que apenas uma delas se 
torne Direito positivo no ato do órgão aplicador do Direito - no ato do tribunal, especialmente." (KELSEN, 1998, p. 390/391)

4 Para Carl Schmitt $(2001,179):$ “Para o jurista do tipo decisionista não é o comando enquanto comando, mas a autoridade ou soberania de uma decisão última, dada como comando, que constitui a fonte de todo e qualquer 'direito', isto é, de todas as normas e ordenamentos seguintes" (SCHMITT, 2001, 179).

5 Para Hart (2009, p. 129), “[...] só podemos apresentar claramente essas verdades e avaliar corretamente sua importância se supusermos um contexto social mais complexo no qual, para a identificação de normas primárias de obrigação, seja aceita e utilizada uma norma secundária de reconhecimento. Se algo merece ser denominado fundamento de um sistema jurídico, trata-se dessa situação" (HART, 2009. p. 129). Além disso, Hart reconhecia que "Num sistema jurídico moderno, no qual existem várias 'fontes' do direito, a norma de reconhecimento é correspondentemente mais complexa: os critérios para identificar a norma jurídica são múltiplos e geralmente incluem uma constituição escrita, a promulgação pelo legislativo e precedentes judiciais" (HART, 2009, p. 130).

6 "Dado que as normas jurídicas como prescrições, isto é, enquanto comandos, permissões, atribuições de competência, não podem ser verdadeiras nem falsas, põe-se a questão de saber como é que os princípios lógicos, particularmente o princípio da não-contradição e as regras da concludência do raciocínio, podem ser aplicados à relação entre normas (como desde sempre tem feito a Teoria Pura do Direito) quando, segundo a concepção tradicional, estes princípios apenas são aplicáveis a proposições ou enunciados que possam ser verdadeiros ou falsos. A resposta a esta questão é a seguinte: os princípios lógicos podem ser, se não direta, indiretamente, aplicados às normas jurídicas, na medida em que podem ser aplicados às proposições jurídicas que descrevem estas normas e que, por sua vez, podem ser verdadeiras ou falsas. Duas normas jurídicas contradizem-se e não podem, por isso, ser afirmadas simultaneamente como válidas quando as proposições jurídicas que as descrevem se contradizem; e uma norma jurídica pode ser deduzida de uma outra quando as proposições jurídicas que as descrevem podem entrar num silogismo lógico." (KELSEN, Hans. Op. cit. p. 83/84)

7 "Também o princípio da chamada apreciação dos interesses é tão-só uma formulação, e não qualquer solução, do problema que aqui nos ocupa. Não fornece a medida ou critério objetivo segundo o qual os interesses contrapostos possam ser entre si comparados e de acordo com o qual possam ser dirimidos os conflitos de interesses. Especialmente, tal critério não pode ser retirado da norma interpretanda, da lei que a contém ou da ordem jurídica global, como pretende a teoria chamada da ponderação dos interesses. Com efeito, a necessidade de uma interpretação resulta justamente do fato de a norma aplicar ou o sistema das normas deixarem várias possibilidades em aberto, ou seja, não conterem ainda qualquer decisão sobre a questão de saber qual dos interesses em jogo é o de maior valor, mas deixarem antes esta decisão, a determinação da posição relativa dos interesses, a um ato de produção normativa que ainda vai ser posto - à sentença judicial, por exemplo." (KELSEN, 1998, p. 392)

8 "No presente trabalho chamo expressamente a atenção, em notas no final do livro, para as mais importantes alterações. Trata-se quase sempre do desenvolvimento mais consequente de princípios; no conjunto - assim o espero -, dos frutos de uma explicitação ou desimplicação que deflui de tendências que são imanentes à própria teoria, a qual permanece inalterada quanto ao seu núcleo essencial" (KELSEN, 1998, p. X).

9 Com efeito, para Ferrara: "O juiz, porém, está submetido às leis, decide como a lei ordena, é o executor e não o criador da lei. A sua função específica consiste na aplicação do direito" (FERRARA, 1963, p. 111).

10 Segundo Ferrara, "a vida jurídica todos os dias oferece ocasião para se tirarem novos princípios das palavras da lei que subsistem de modo autónomo como vontade objectivada do poder legislativo" (FERRARA, 1963, p. 135).

11 "Frequentemente um só preceito de lei encerra dentro de si vários princípios, dos quais apenas um está expresso, enquanto que os outros podem derivar-se por dedução lógica; além disso a conexão das várias normas faz com que algumas se apresentem como regras e outras como excepções. Ora o intérprete deve tirar dos princípios todas as consequências de que são capa- 
zes, embora algumas sejam expressas, enquanto que outras permanecem latentes. Os preceitos jurídicos têm um conteúdo virtual que é função do intérprete extrair e desenvolver. Assim se enriquece e elabora o material jurídico." (FERRARA, 1963, p. 153)

12 "Se pelo contrário a incompatibilidade tem lugar entre urna disposição principal e uma disposição secundária e acessória, então leva à ineficácia da última, deixando firme a disposição fundamental. [...] Assim também há contradição entre o princípio fundamental que admite a acção de manutenção unicamente para a posse de bens imóveis ou de universalidades de móveis (art. 694.0) e a disposição processual que para fins de competência supõe uma acção de turbação para a posse de coisas móveis (cód. de proc. civ., art. 93.0). Em tal caso a norma acessória processual é sacrificada e considera-se como não escrita". (FERRARA, 1963, p. 152)

13 "Se por lacunas se entendem vazios incolmatáveis do ordenamento jurídico, deficiências que não se integrar com meios jurídicos, então deve partir-se do princípio que o direito não tem lacunas e que para todo o caso não previsto ocorre sempre uma norma jurídica desenvolvida e elaborada no sistema. Isto vale, pelo menos quanto ao direito privado" (FERRARA, 1963, p. 155). E continua o autor: "Por isso, embora o direito positivo não apresente disposição especial para certa matéria ou caso, há nele, porém, capacidade e força latente para a elaborar, e contém os germes de uma série indeterminada de normas não expressas, mas ínsitas e viventes no sistema. Com efeito, se duma só disposição ou dum grupo de normas se deduz um princípio jurídico mais amplo, é de concluir, na dúvida, que, visto ter aplicado semelhante princípio no caso particular, a ordem jurídica o aprova na sua generalidade, e portanto todas as consequências que do princípio derivam" (FERRARA, 1963, p. 157).

14 Para Ferrara, a aplicação lógica ou racional possui um elemento sistemático, onde "um princípio jurídico não existe isoladamente, mas está ligado por nexo íntimo com outros princípios. 0 direito objectivo, de facto, não é um aglomerado caótico de disposições, mas um organismo jurídico, um sistema de preceitos coordenados ou subordinados, em que cada um tem o seu posto próprio". Segundo ele, "há princípios jurídicos gerais de que os outros são deduções e corolários, ou então vários princípios condicionam-se ou restringem-se mutuamente, ou constituem desenvolvimentos autónomos em campos diversos. Assim todos os princípios são membros dum grande todo." (FERRARA, 1963, p. 143)

15 "Tratando-se de delito político praticado em data anterior à lei que veda, nesse caso, o livramento condicional, não pode ser negado esse favor sem ofensa do princípio da irretroatividade da lei penal mais grave." (Supremo Tribunal Federal, 1941, p. 81)

16 “A aplicação, no direito penal, do princípio 'Sententia debet esse conformis libello' somente se dá nos limites necessários a evitar surpresas ao réu e cerceamento de defesa." (Supremo Tribunal Federal, 1951, p. 10)

17 “I- Obrigação do contribuinte de atender às exigências necessárias ao lançamento do imposto de renda. II - A rebeldia na recusa de informações e a própria reticência justificam a aplicação de multas e o cálculo "ex officio". III - Essas conclusões exigidas em toda a parte pela natureza do tributo não colidem com o princípio genérico de que a falta de recurso administrativo não prejudica a amplitude da defesa judicial. IV - Os fatos não autorizam a considerar a negligência do contribuinte, não convencido, aliás, da sua obrigação do imposto, por não terem seus vencimentos em autarquia única fonte tributável, atingido ao mínimo legal." (Supremo Tribunal Federal, 1945, p. 197)

18 "Art. 177 da Lei de Falências. 0 princípio da 'acusatio nata". No caso de falência fraudulenta, a prescrição se verifica dois anos após o encerramento do processo de falência ou de cumprida a concordata, ainda que a ação penal se haja instaurado no decurso do processo de falência. A pronúncia interrompe a prescrição. Este efeito, porém, perde de relevo no caso especial em que a prescrição tem seu marco inicial especialmente determinado em momento que pode ser posterior a pronúncia." (Supremo Tribunal Federal, 1943, p. 169)

19 “O princípio 'nullum crimen, nulla poena sine lege' é invocável nos casos de multa fiscal. Improcedência de executivo fiscal." (Supremo Tribunal Federal, 1942, p. 206)

20 "O princípio da liberdade contratual subsiste, cedendo, porém, a imposições contrárias dos bons costumes e do bem público. 0 art. 2 do decreto 22.626 de 7 de abril de 1933 deixou incólume, por não ter efeito retroativo, qualquer comissão estabelecida, nos contratos de mútuo, antes 
de sua vigência. A comissão, porém, que não representa quantia realmente mutuada não pode ser considerada para o efeito de produzir juros que se tornariam superiores ao máximo que a lei estabelece. A permissão contida no decreto lei n. 182, de 5 de janeiro de 1938 não tem força retro-operante." (Supremo Tribunal Federal, 1941, p. 157)

21 'Redução do 'quantum' de multa fiscal, por amor de princípio da 'lex mitior'. (Supremo Tribunal Federal, 1944, p. 223)

22 “Bens inalienáveis. Cod. Civil, arts. 530, I, 531, 533 e 860, § único do Código Civil. Multa fiscal não compensatória e o princípio da aplicação retro operante da lei mais branda." (Supremo Tribunal Federal, 1947, p. 1)

23 "Mas cabe acrescentar que os valores não entram no sistema jurídico apenas por via dos princípios, senão também mediante regras, como já demonstramos acima com vários exemplos referentes a preceitos constitucionais e legais. A diferença na programação seletiva de conteúdos valorativos parece ser a seguinte: os princípios, que se estruturam tipicamente mediante uma relação mais elástica entre "se" e "então", ou seja, entre antecedente e consequente, tendem a envolver uma postura mais flexível e aberta em face da incorporação de valores; as regras, que se estruturam por uma conexão "se-então" menos elástica, tendem a implicar uma atitude mais estreita e menos aberta para a incorporação de valores. [...] Tanto há princípios quanto regras que se referem imediata, direta e explicitamente a valores e fins, como há princípios que não se caracterizam por essa maneira de referência a eles." (NEVES, 2013, p. 41).

24 "Com frequência, fala-se de generalidade para referir-se ao problema da imprecisão. Daí a confusão em que se pode cair quando se consideram as regras e princípios a que me referi exemplificativamente. Mas, inclusive a tese da generalidade é compreendida em termos de imprecisão, não prevalece a distinção entre princípios e regras com base neste critério, conforme argumentos apresentados acima. Pode-se, sim, afirmar que os princípios tendem a ser mais gerais e imprecisos do que as regras. A esse respeito, Alexy sustenta que 'uma razão para que os princípios, em regra, apresentem um maior grau de generalidade reside no fato de que eles não se relacionam com as fronteiras das possibilidades do mundo fático e normativo. Mas cumpre insistir que esta característica não tem uma relação necessária, mas sim eventual (embora se possa falar em tendencial) com sua maior generalidade e imprecisão em relação às regras" (NEVES, 2013, p. 25).

25 'Algumas vezes empregamos 'poder discricionário' em sentido fraco, apenas para dizer que, por alguma razão, os padrões que uma autoridade pública deve aplicar não podem ser aplicados mecanicamente, mas exigem uso da capacidade de julgar. [...] Às vezes usamos a expressão em um segundo sentido fraco, apenas para dizer que algum funcionário público tem a autoridade de tomar uma decisão em última instância e que esta não pode ser revista e cancelada por nenhum outro funcionário. [...] Chamo esses dois sentidos fracos para diferenciá-los de um sentido mais forte. Às vezes usamos 'poder discricionário' não apenas para dizer que um funcionário público deve usar seu discernimento na aplicação dos padrões que foram estabelecidos para ele pela autoridade ou para afirmar que ninguém irá rever aquele exercício de juízo, mas para dizer que, em certos assuntos, ele não está limitado pelos padrões de autoridade em questão." (DWORKIN, 2010, pp. 51/52)

26 “(1) Um positivista poderia argumentar que os princípios não podem ser vinculantes ou obrigatórios. Tal argumento seria um erro. Sem dúvida, é sempre questionável se algum princípio particular obriga, de fato, alguma autoridade jurídica. Mas não há nada no caráter lógico de um princípio que o torne incapaz de obrigá-la. [...] (2) Um positivista poderia argumentar que embora alguns princípios sejam obrigatórios, no sentido de que o juiz deve levá-los em consideração, eles não podem prescrever um resultado particular. [...] Esta não parece uma razão para concluir que juízes que devem haver-se com princípios possuam poder discricionário, já que um conjunto de princípios pode ditar um resultado." (DWORKIN, 2010, pp. 56/57)

27 E continua: "Assim, o padrão que estabelece que os acidentes automobilísticos devem ser reduzidos é uma política e o padrão segundo o qual nenhum homem deve beneficiar-se de seus próprios delitos é um princípio." (DWORKIN, 2010, p. 36)

28 "O direito como integridade nega que as manifestações do direito sejam relatos factuais do convencionalismo, voltados para o passado, ou programas instrumentais do pragmatismo jurídico, 
voltados para o futuro. Insiste em que as afirmações jurídicas são opiniões interpretativas que, por esse motivo, combinam elementos que se voltam tanto para o passado quanto para o futuro; interpretam a prática jurídica contemporânea como uma política em processo de desenvolvimento. Assim, o direito como integridade rejeita, por considerar inútil, a questão de se os juízes descobrem ou inventam o direito; sugere que só entendemos o raciocínio jurídico tendo em vista que os juízes fazem as duas coisas e nenhuma delas." (DWORKIN, 2007, p. 271)

29 "Na adequação dos discursos de fundamentação resultantes do consenso democrático em situações concretas, Dworkin recorre, por sua vez, a um procedimento de interpretação construtiva que permitiria ao juiz chegar, em todos os casos, a uma decisão idealmente válida que compensasse a indeterminação do direito" (CARNEIRO, 2009, p. 208).

30 "Ao deixar-se conduzir pela ideia da realização de valores materiais, dados preliminarmente no direito constitucional, o tribunal constitucional transforma-se numa instância autoritária. No caso de uma colisão, todas as razões podem assumir o caráter de argumentos de colocação de objetivos, o que faz ruir a viga mestra introduzida no discurso jurídico pela compreensão deontológica de normas e princípios do direito. A partir do momento em que direitos individuais são transformados em bens e valores, passam a concorrer em pé de igualdade, tentando conseguir a primazia em cada caso singular. Cada valor é tão particular como qualquer outro, ao passo que normas devem sua validade a um teste de universalização. [...] Isso leva a Dworkin a entender direitos como 'trunfos' a serem usados contra argumentos de colocação de objetivos. [...] Normas e princípios possuem uma força de justificação maior do que a de valores, uma vez que podem pretender, além de uma especial dignidade de preferência, uma obrigatoriedade geral, devido ao seu sentido deontológico de validade; valores têm que ser inseridos, caso a caso, numa ordem transitiva de valores. [...] Na medida em que um tribunal constitucional adota a doutrina da ordem de valores e a toma como base de sua prática de decisão, cresce o perigo dos juízos irracionais, porque, neste caso, os argumentos funcionalistas prevalecem sobre os normativos." (HABERMAS, 2010, pp. 320/321)

31 "Seguindo I. Maus, ele adere à proposta de R. Alexy, a qual consistem em interpretar princípios transformados em valores como mandamentos de otimização, de maior ou menor intensidade. Essa interpretação vem ao encontro do discurso da 'ponderação de valores', corrente entre juristas, o qual, no entanto, é frouxo" (HABERMAS, 2010, p. 315).

32 "Os direitos fundamentais, ao contrário, ao serem levados a sério em seu sentido deontológico, não caem sob uma análise dos custos e vantagens" (HABERMAS, 2010, p. 322).

33 Para Habermas, "Uma tal teoria reconstrutiva do direito deve ser suficientemente seletiva, a fim de permitir precisamente uma decisão correta, a qual define quais as pretensões que um partido pode fazer valer no quadro da ordem jurídica existente, o que equivale a dizer quais os direitos que lhe competem objetivamente. A teoria do juiz Hércules reconcilia as decisões racionalmente reconstruídas do passado com a pretensão à aceitabilidade racional do presente, ou seja, reconcilia a história com a justiça" (HABERMAS, 2010, p. 264). E continua: "A teoria de Dworkin serviu como fio condutor para analisarmos o problema da racionalidade da jurisdição, cujas decisões devem satisfazer, simultaneamente, a critérios de segurança do direito e da aceitabilidade racional" (HABERMAS, 2010, p. 297).

34 "A complexidade simples (em caso de se poder usar esta expressão paradoxal) permitiria conectar todos os elementos; a complexidade complexa necessitaria de seleção e, consequentemente, de um aumento progressivo de suas próprias exigências. Este tipo de complexidade é, portanto, seletivo, contingente, e conta com maior capacidade de variação." Luhmann conclui, então, que, na Teoria dos Sistemas, "já não é possível trabalhar atualmente com o conceito de complexidade simples" (LUHMANN, 2011, p. 185).

35 "Essa compreensão levou diretamente à indagação de como um sistema (menos complexo) poderia estabelecer uma relação com o meio (mais complexo). [...] 0 sistema não tem capacidade de apresentar uma variedade suficiente (requisite variety: Ashby) para responder, ponto por ponto, à imensa possibilidade de estímulos provenientes do meio. Assim, o sistema requer o desenvolvimento de uma disposição especial para a complexidade, no sentido de ignorar, rechaçar, criar indiferenças, enclausurar-se em si mesmo. Por isso, surgiu a expressão redução de complexidade, no que se refere à relação do sistema com o meio, mas também consigo mesmo, 
principalmente quando se tratava de compreender as instâncias da racionalidade, as agências de planejamento localizadas no interior do próprio sistema" (LUHMANN, 2011, p. 179). E continua: "A afirmação mais abstrata que se pode fazer sobre um sistema, e que é válida para qualquer tipo de sistema, é a de que entre sistema e meio há uma diferença, que pode ser descrita como diferença de complexidade: o meio de um sistema é sempre mais complexo do que o sistema" (LUHMANN, 2011, pp. 183/184).

36 "A consequência é que para ordens quantitativamente grandes os elementos podem se conectar somente sob a condição de que este acoplamento se realize de maneira seletiva" (LUHMANN, 2011, p. 184).

37 "Lo decisivo es -y esto sería lo que el concepto de «acoplamiento estructural- hace visible- que el reforzamiento de la irritación recíproca permanezca como algo que depende del efecto de exclusión de ese mismo mecanismo. La indiferencia recíproca es lo único que hace posible que aumente una dependencia recíproca específica. Con esta condición -que debe entenderse como una diferenciación funcional en relación al sistema de la sociedad- los sistemas disuelven la estructura circular de su autorreferencia por medio de la externalización. El sistema jurídico, al preparar las posibilidades de legislación se ve expuesto, él mismo, a influencias de carácter político. Con la democratización, el sistema político se expone a sí mismo a los atractivos de decidir iniciativas para la modificación del derecho. La autorreferencia toma, entonces, la vía indirecta que pasa por la inclusión del entorno en el sistema. De este modo, las asimetrías jerárquicas resultan prescindibles, una vez que la mirada hacia arriba ha perdido todo apoyo" (LUHMANN, 2002, p. 346).

38 "La democratización del sistema político y la positivización del derecho se han podido desarrollar gracias a la posibilitación y estimulación recíprocas" (LUHMANN, 2002, p. 313).

39 "Las operaciones de los sistemas se identifican por separado, porque son ellos mismos los que al reproducirse deciden sobre sus propios límites. Esto ocurre con la ayuda de un código específicamente propio. En el sistema político esto se lleva a cabo por medio de la respectiva distinción del poder en turno entre (poder ministerial) y sus subordinados (gobernantes/gobernados), así como por el código del poder ministerial que se expresa en el esquema: gobierno/oposición. En el sistema jurídico la codificación descansa en una distinción totalmente diversa: lo conforme con el derecho/lo discrepante con el derecho. Correspondientemente divergen los programas que regulan la distribución de los valores positivos y negativos del código, y correspondientemente divergen tanto las condiciones con las que se reconoce lo que le pertenece al sistema, como el establecimiento de lo que para el sistema es entorno. Si esta capacidad de distinguir y de incluir sistemas no funcionara, las consecuencias serían el caos y la simplificación extrema. Cada decisión jurídica, cada cierre de contrato, sería una acción política; y, al revés, el político con sus comunicaciones tan sólo podría interpretar o modificar situaciones jurídicas, lo que lo obligaría a comportarse con demasiada cautela" (LUHMANN, 2002, p. 312).

40 Aqui, faz-se a distinção entre persuadir e convencer, a partir da perspectiva de Perelman e Tyteca: "Para quem se preocupa com o resultado, persuadir é mais do que convencer, pois a convicção não passa da primeira fase que leva à ação [...] Em contrapartida, para quem está preocupado com o caráter racional da adesão, convencer é mais do que persuadir. [...] Segundo Dumas, na persuasão, o indivíduo 'se contenta com razões afetivas e pessoais', sendo a persuasão em geral 'sofística' [...] Propomo-nos chamar persuasiva a uma argumentação que pretende valor só para um auditório particular e chamar convincente àquela que deveria obter a adesão de todo ser racional." (PERELMAN; OLBRECHTS-TYTECA, 2005, pp. 30/31)

41 'A 'Retórica' tem uma má reputação entre as pessoas por conta da notória possibilidade de um bom orador vencer um debate público mesmo defendendo uma má ideia. [...] Uma forma de fazer frente a isso é relacionar a persuasão a um auditório ideal ou universal." (MACCORMICK, 2008, p. 27)

42 Para Perelman e Tyteca, o auditório universal seria "constituído pela humanidade inteira, ou pelo menos por todos os homens adultos e normais [...]". E continua: "Uma argumentação dirigida a um auditório universal deve convencer o leitor do caráter coercitivo das razões fornecidas, de sua evidência, de sua validade intemporal e absoluta, independente das contingências locais e históricas. [...] 0 auditório universal é constituído por cada qual a partir do que sabe dos seus 
semelhantes, de modo a transcender as poucas oposições de que tem consciência. Assim, cada cultura, cada indivíduo tem sua própria concepção do auditório universal [...]" (PERELMAN, 2005, pp. 33, 35 e 37)

43 Nesse sentido, José Rodrigo Rodriguez entende ser cabível a redução da insegurança jurídica a partir da argumentação: “[...] esse legislador hipotético deve levar em conta que é possível criar segurança jurídica a partir da argumentação, ou seja, a partir de mecanismos voltados para estabelecer critérios que sirvam para fundamentar argumentativamente as decisões. Mesmo diante de uma norma aberta, é possível criar constrangimentos à fundamentação que resultem no proferimento de decisões relativamente padronizadas" (RODRIGUEZ, 2013, pp. 228/229).

\section{REFERÊNCIAS}

ALEXY, Robert. Direitos fundamentais, ponderação e racionalidade. In: CLÈVE, Clèmerson Merlin; BARROSO, Luís Roberto (org.). Direito constitucional: teoria geral da constituição. São Paulo: Revista dos Tribunais, 2011a. p. 721-732

. Teoria dos Direitos Fundamentais (trad. Virgílio Afonso da Silva). 2. ed. São Paulo: Malheiros, 2011.

BARROSO, Luís Roberto. Curso de direito constitucional contemporâneo: os conceitos fundamentais e a construção do novo modelo. 3. ed. São Paulo: Saraiva, 2011b.

Neoconstitucionalismo e constituicionalização do direito. In: CLÈVE, Clèmerson Merlin; BARROSO, Luís Roberto (org.). Direito constitucional: teoria geral da constituição. São Paulo: Revista dos Tribunais, 2011. p. 143-195.

CALSAMIGLIA, Albert. Postpositivismo. Doxa, 21, n. 1, p. 209-220, 1998. p. 218

CARNEIRO, Wálber Araujo. Hermenêutica jurídica heterorreflexiva: limites e possibilidades de uma filosofia do direito. $301 \mathrm{f}$. Tese (Doutorado em Direito) Programa de Pós-Graduação em Direito, Universidade do Vale do Rio dos Sinos, São Leopoldo, RS, 2009.

CARVALHO NETTO, Menelick de; SCOTTI, Guilherme. Os direitos fundamentais e a (in)certeza do direito: a produtividade das tensões principiológicas e a superação do sistema de regras. Belo Horizonte: Fórum, 2011.

COSTA, Alexandre Araújo. Judiciário e interpretação: entre Direito e Política. Pensar, Fortaleza, v. 18, n. 1, p. 9-46, jan./abr. 2013. 
DWORKIN, Ronald. Levando os direitos a sério (trad. Nelson Boeira). 3. ed. São Paulo: Martins Fontes, 2010.

. O império do direito (trad. Jefferson Luiz Camargo). 2. ed. São Paulo: Martins Fontes, 2007.

FERRARA, Francesco. Interpretação e aplicação das leis (trad. Manuel A. D. de Andrade). 2. ed. Coimbra: Arménio Amado, 1963.

FERRAZ JR., Tercio Sampaio. Direito, Retórica e Comunicação: subsídios para uma pragmática do discurso jurídico. 3. ed. São Paulo: Atlas, 2015.

GICO JR., Ivo. Análise econômica do processo civil. Indaiatuba, SP: Foco, 2020.

HABERMAS, Jürgen. Direito e democracia: entre faticidade e validade. v. 1 (trad. Flávio Beno Siebeneichler). Rio de Janeiro: Tempo Brasileiro, 2010.

HART, H. L. A. O conceito de direito. (trad. Antônio de Olveira Sette-Câmara). São Paulo: Martins Fontes, 2009.

KELSEN, Hans. Teoria pura do direito (trad. João Baptista Machado). 6. ed. São Paulo: Martins Fontes, 1998.

LACERDA, Gustavo Biscaia de. Augusto Comte e o "positivismo" redescobertos. Revista de Sociologia e Política, Curitiba, v. 17, n. 34, p. 319-343, out. 2009.

LUHMANN, Niklas. El derecho de la sociedade. México: Universidade Iberoamericana, 2002.

Introdução à Teoria dos Sistemas (trad. Ana Cristina Arantes Nasser). 3. ed. Petrópolis, RJ: Vozes, 2011.

MACCORMICK, Neil. Retórica e o Estado de Direito (trad. Conrado Hübner Mendes). Rio de Janeiro: Elsevier, 2008.

MONTESQUIEU, Charles de Secondat, Baron de. O Espírito das Leis (trad. Cristina Murachco). 3. ed. São Paulo: Martins Fontes, 2005. 
NEVES, Marcelo. Entre Hidra e Hércules: princípios e regras constitucionais como diferença paradoxal do sistema jurídico. São Paulo: Martins Fontes, 2013.

.Entre Têmis e Leviatã: uma relação difícil: o Estado Democrático de Direito a partir e além de Luhmann e Habermas. 2. ed. São Paulo: Martins Fontes, 2008.

PERELMAN, Chaïm; OLBRECHTS-TYTECA, Lucie. Tratado da argumentação: a nova retórica. 2. ed. São Paulo: Martins Fontes, 2005.

RODRIGUEZ, José Rodrigo. Como decidem as cortes? Para uma crítica do Direito (brasileiro). Rio de Janeiro: FGV, 2013.

SCHMITT, Carl. Sobre os três tipos de pensamento jurídico (trad. Peter Naumann). In: MACEDO Jr., R. P. Carl Schmitt e a fundamentação do direito. São Paulo: Max Limonad, 2001.

VIEHWEG, Theodor. Tópica e jurisprudência (trad. Tercio Sampaio Ferraz Jr.). Brasília: Universidade de Brasília, 1979. 1997. Tópica y filosofía del derecho (trad. Jorge M. Seña). 2. ed. Barcelona: Gedisa, Recebido em: 13-11-2018 Aprovado em: 26-10-2020 


\section{Fabrício Castagna Lunardi}

Doutor e Mestre em Direito pela Universidade de Brasília (UnB). Bacharel em Direito pela Universidade Federal de Santa Maria (UFSM). Juiz de Direito do Tribunal de Justiça do Distrito Federal e Territórios - TJDFT (desde 2009). Professor do Programa de Mestrado em Direito, área de concentração Direito e Poder Judiciário, da Escola Nacional de Formação e Aperfeiçoamento de Magistrados (ENFAM), onde também é docente, formador, tutor e conteudista em cursos de formação e aperfeiçoamento. Professor da Escola de Formação Judiciária do TJDFT. Docente em diversas outras Escolas Judiciais, já tendo ministrado cursos de formação e/ou aperfeiçoamento para as Escolas do TJSP, TJAL, TJAC, TJPA, TRF2, TJMG, TJES, entre outras. E-mail: fabricioclunardi@ yahoo.com.br

Escola Nacional de Formação e Aperfeiçoamento de Magistrados - ENFAM St. de Clubes Esportivos Sul Trecho 3 - Asa Sul, Brasília - DF, 70200-003 Escola Nacional de Formação e Aperfeiçoamento de Magistrados, ENFAM 
